\title{
Inheritance of rice cold tolerance at the germination stage
}

\author{
Renata Pereira da Cruz ${ }^{1}$, Sandra Cristina Kothe Milach ${ }^{2}$ and Luiz Carlos Federizzi ${ }^{3}$ \\ ${ }^{1}$ Instituto Rio Grandense do Arroz, Cachoeirinha, RS, Brazil. \\ ${ }^{2}$ Pioneer Sementes, Passo Fundo, RS, Brazil. \\ ${ }^{3}$ Universidade Federal do Rio Grande do Sul, Faculdade de Agronomia, Departamento de Plantas de \\ Lavoura, Porto Alegre, RS, Brazil.
}

\begin{abstract}
Cold tolerance during germination is important for ensuring fast and uniform establishment of a rice crop early in the season. However, evaluation of this trait under field conditions is limited by environmental variation, which makes it difficult to identify genetically superior lines. Evaluation of cold tolerance under controlled temperature conditions may be performed by assessing percentage of reduction in coleoptile length and coleoptile growth. Our study determined the inheritance and heritability of cold tolerance at the germination stage in crosses between six rice genotypes. Diallel analysis showed that while both additive and non-additive gene action were involved, the non-additive action was relatively more important for percentage of reduction in coleoptile length and coleoptile growth. Our data shows that genotype Quilla 66304 would be the best parent in crosses aimed at increasing cold tolerance at the germination stage in rice due to its high general combining ability for both percentage of reduction in coleoptile length and coleoptile growth. Generation mean analysis was also performed for coleoptile growth in six cold-sensitive $\mathrm{x}$ cold-tolerant crosses and proved that non-additive effects were due to dominance and epistatic interactions. Though broad sense heritability values were high, the relative importance of the non-additive effects suggests that selection should be applied in advanced generations of the breeding program.
\end{abstract}

Key words: chilling tolerance, Oryza sativa, rice genetics, seed germination.

Received: December 6, 2004; Accepted: October 10, 2005.

\section{Introduction}

Low temperature is probably one of the most common environmental stresses encountered during germination by summer crops sown early in the season (Blum, 1988). For rice (Oryza sativa L.), temperatures lower than $20{ }^{\circ} \mathrm{C}$ decrease both the speed and percentage of germination (Yoshida, 1981) and result in lower crop stands and higher production costs. In the southern Brazilian state of Rio Grande do Sul the average minimum temperature in October, when rice is seeded, is about $12{ }^{\circ} \mathrm{C}$, so cold tolerance is needed to ensure a fast and uniform establishment of the rice crop.

There is genetic variability in $O$. sativa for cold tolerance at germination with the subspecies Japonica providing the main source of variation to cold tolerance (Takahashi, 1984). In Rio Grande do Sul breeding programs Japonica genotypes are crossed to $O$. sativa subspecies Indica geno-

Send correspondence to Renata Pereira da Cruz. Instituto Rio Grandense do Arroz, Av. Bonifácio Carvalho Bernardes 1494, Caixa Postal 29, 94.930-030 Cachoeirinha, RS, Brazil. E-mail: rpdacruz@hotmail.com. This study is part of the doctoral thesis of this author. types that have adequate plant type and good grain quality for the Brazilian market. During such crosses the production of superior recombinant genotypes depends on the mode of gene action and on the combining ability of the parents, so selection of the most adequate parents to be used in crosses is very important in obtaining superior genetic combinations.

Combining ability analysis has been widely used as a means of testing the performance of genotypes in hybrid combinations and for characterizing the nature and magnitude of gene action (Kaw et al., 1986). The few studies conducted on diallel analysis of cold tolerance in rice are related to the vegetative stage ( $\mathrm{Li}$ and Rutger, 1980; Datta and Siddiq, 1983; Kaw and Khush, 1986; Kaw et al., 1986), with the results obtained depending on the trait measured. For example, in the case of leaf discoloration (Datta and Siddiq, 1983) and plant stature (Li and Rutger, 1980; Kaw and Khush, 1986) an additive gene action was found but when plant weight, root length and plant height reduction were considered a non-additive gene action was most important (Datta and Siddiq, 1983). So, based on the reports of 
these authors, the nature of gene action appears to vary according to the tolerance component evaluated.

The mode of inheritance is also very important in defining the selection strategy to be applied in a breeding program. There are a few studies related to the genetic basis of rice cold tolerance at the germination stage, with the main available information being the papers published by Sasaki et al. (1973) apud Sthapit and Witcombe (1998) and Sasaki (1977) apud Takahashi (1997). The data from these reports indicate that the low temperature germination of rice is controlled by four or more dominant genes and that both additive and non-additive effects are involved, although transgressive segregation and the absence of a maternal effect were also reported. More recently, Sthapit and Witcombe (1998), evaluating germination index in $\mathrm{F}_{3}$ families submitted to $17{ }^{\circ} \mathrm{C}$ for seven days, related a high heritability for the character, varying from 0.7 to 0.9 .

Until now there has been no information for Brazilian rice genotypes about the genetics of cold tolerance during the initial stages of germination and the objectives of this study were therefore to determine the general and specific combing ability of six rice genotypes, the predominant gene action involved and the inheritance and heritability of cold tolerance at the germination stage.

\section{Material and Methods}

\section{Genetic material and crosses}

Six Oryza sativa rice genotypes with different cold reactions at the germination stage were crossed in a diallel consisting of 15 combinations. Three genotypes (IRGA 417, BRS 7 and IR 8) belonged to the cold-sensitive Indica subspecies and the other three (Quilla 64117, Quilla 66304 and Diamante) belonged to the cold-tolerant Japonica subspecies. Reciprocal crosses were not performed because there was no indication of maternal inheritance for cold reaction (Sasaki, 1977 apud Takahashi, 1997). The $F_{1}$ plants from six crosses (sensitive $x$ tolerant) were further advanced to the $\mathrm{F}_{2}$ generation and also backcrossed to each parent to obtain the $\mathrm{BC}_{1} \mathrm{~F}_{1}$ and $\mathrm{BC}_{2} \mathrm{~F}_{1}$ generations.

\section{Cold tolerance evaluation}

Rice cold tolerance at germination was evaluated by the percentage of reduction in coleoptile length due to cold and coleoptile growth after a cold stress. Before the beginning of the experiments, all the seeds of the parents, $F_{1}$ and segregating generations were washed with aqueous ethanol $(70 \% \mathrm{v} / \mathrm{v})$ for $30 \mathrm{~s}$ followed by immersion in aqueous sodium hypoclorite $(5 \% \mathrm{v} / \mathrm{v})$ for $20 \mathrm{~min}$ to prevent contamination and then washed six times with sterile distilled water.

Percentage of reduction in coleoptile length was measured by placing 20 seeds of each of the six parents and 10 seeds of each of the $15 \mathrm{~F}_{1}$ hybrids in Petri dishes containing germination paper moistened with sterile distilled water and germination allowed to proceed at $28^{\circ} \mathrm{C}$ for seven says (control) and $13{ }^{\circ} \mathrm{C}$ for 30 days (cold treatment). In each of these treatments the experiment was conducted in a randomized block design with three replicates, where the blocks corresponded to different shelves in the germination chamber and each replication was the mean of the measurements for the seeds in a same Petri dish. At the end of each germination period the coleoptile length of each seed was measured and the final data were expressed as percentage of reduction in coleoptile length, obtained by comparing the cold-treated seeds with the control seeds for each genotype and $\mathrm{F}_{1}$ hybrid.

Coleoptile growth was measured using two separate experiments, one for the six parents and the $15 \mathrm{~F}_{1}$ hybrids (diallel) and another for the $\mathrm{P}_{1}, \mathrm{P}_{2}, \mathrm{~F}_{1}, \mathrm{~F}_{2}, \mathrm{BC}_{1} \mathrm{~F}_{1}$ and $\mathrm{BC}_{2} \mathrm{~F}_{1}$ generations (generation means) of six cold-sensitive $\mathrm{x}$ cold-tolerant crosses. The diallel experiment methodology consisted of soaking the seeds in sterile distilled water for $20 \mathrm{~h}$ at $25^{\circ} \mathrm{C}$ and then placing them on a folded germination paper moistened with sterile distilled water. In each fold of the paper 10 seeds were carefully placed with the embryo side up to allow the coleoptile length to be determined later. This type of experiment was conducted in a completely randomized design with three replicates $(n=30$ seeds), each corresponding to the mean of the ten seeds per fold of germination paper for both the parents and the $\mathrm{F}_{1}$ generation. In the generation means experiment, 30 seeds were also evaluated per parent, while for the other generations a variable number of seeds were evaluated according to their availability. In this experiment the folded germination papers were put in plastic trays covered with a polyethylene film to prevent desiccation. The trays were taken to the germination chamber where the following temperature regime was imposed: $28^{\circ} \mathrm{C}$ for two days; $13^{\circ} \mathrm{C}$ for three days (cold stress) and $28^{\circ} \mathrm{C}$ for two days. The coleoptile length of the seeds was measured twice during this period, once after the cold stress (first measurement) and again at the end of the experiment (second measurement). Cold tolerance was expressed as coleoptile growth under normal temperature after the cold period, which corresponded to the difference between the second and the first measurements.

\section{Statistical analysis}

Data for percentage of reduction in coleoptile length and coleoptile growth for the parent plants was normally distributed and were thus submitted to analysis of variance (ANOVAR) and comparison of means using Duncan's test $(\alpha=0.05)$.

Cold tolerance inheritance was studied through diallel analysis for both traits and, in the case of coleoptile growth, generation means analysis was also used, as this trait is suitable to be measured in segregant generations. Diallel analysis was performed according to Griffing (1956), considering a fixed model and method two that esti- 
mates the general and specific combining effects with $p(p+1) / 2$ combinations without the reciprocals.

The genetic effects were estimated by the six parameter model, as in neither of the crosses could the genetics effects be explained by the joint scaling test, three parameter model (Mather and Jinks, 1982). Besides estimating the mean (m), additive ([d]) and dominance ([h]) components, the six parameter model also measures additive $\mathrm{x}$ additive ([i]), additive $\mathrm{x}$ dominance ([j]) and dominance $\mathrm{x}$ dominance ([1]) epistatic effects.

The null hypothesis for each parameter was evaluated with the t-test and the number of degrees of freedom was given by adding the degrees of freedom of each generation that constituted the estimator expression. The non-significant parameters were not considered and the other parameters were re-estimated, and, in these cases, model adjustment was tested by the chi-square $\left(\chi^{2}\right)$ test.

The variances for the $\mathrm{P}_{1}, \mathrm{P}_{2}, \mathrm{~F}_{1}$ and $\mathrm{F}_{2}$ were estimated according to Mather and Jinks (1982).

\section{Results}

\section{Diallel analysis for percentage of reduction in coleoptile length}

Reduction of coleoptile length was inversely proportional to cold tolerance, i.e. the higher the reduction in coleptile length the lower was the cold tolerance. Mean values were higher than $50 \%$ for all the genotypes and hybrids evaluated and, among the parents, the highest reduction in coleoptile length due to low temperature was in the cold sensitive genotype IR 8 and the lowest reduction in length was in the cold tolerant Quilla 66304 genotype (Table 1). The $\mathrm{F}_{1}$ hybrids presented values ranging from $84.9 \%$ for the
BRS 7 x IR 8 (sensitive $x$ sensitive) cross to $50.6 \%$ for the BRS 7 x Quilla 66304 (sensitive x tolerant) cross (Table 1). In the crosses BRS 7 x Quilla 64117, BRS 7 x Quilla 66304, BRS 7 x Diamante, IRGA 417 x Quilla 64117 and IRGA 417 x Quilla 66304 (all sensitive $x$ tolerant) and BRS 7 x IRGA 417 (sensitive $x$ sensitive) the $F_{1}$ mean was lower than that of the parents, indicating over-dominance towards cold tolerance. On the other hand, in the crosses BRS $7 \times$ IR 8 (sensitive x sensitive) and Quilla 66304 x Diamante (tolerant $x$ tolerant) the $F_{1}$ presented a higher mean for percentage of reduction in coleoptile length (lower tolerance) than the parents and so, over-dominance towards cold sensitivity.

According to the diallel analysis the parents differed in relation to the general combining ability (GCA) and the hybrids presented distinct specific combining abilities (SCA) (Table 2). The fact that GCA and SCA were significant indicates that both additive and non-additive gene action are involved in cold tolerance in the genotypes studied, but the magnitude of the quadratic component associated with the SCA indicated predominance of non-additivity.

Negative values for the GCA and SCA effects indicate a contribution to cold tolerance at germination, or lower reduction in coleoptile length due to cold, while positive for the GCA and SCA effects indicate a tendency towards cold sensitivity. The crosses between the cold sensitive genotype BRS 7 and the three cold tolerant genotypes, as well as the cross between IRGA 417 and the cold tolerant Quilla 64117 presented a highly significant negative SCA effect (Table 3), demonstrating the existence of heterosis for cold tolerance. Similarly, in the crosses BRS 7 x IR 8 and Quilla 66304 x Diamante the significance of the positive SCA effects indicated heterosis for cold sensitivity at the germination stage. The GCA effects were significant

Table 1 - Coleoptile length reduction (\%) and coleoptile growth ( $\mathrm{mm})$. Means for the six parents and their $\mathrm{F}_{1}$ hybrids.

\begin{tabular}{|c|c|c|c|c|c|c|}
\hline & \multicolumn{6}{|c|}{ Reduction in coleoptile length (\%) } \\
\hline & IRGA 417 & BRS 7 & IR 8 & Quilla 64117 & Quilla 66304 & Diamante \\
\hline IRGA 417 & $64.4 \mathrm{~cd}^{1}$ & $61.2 \mathrm{c}-\mathrm{f}$ & $68.7 \mathrm{bc}$ & $50.7 \mathrm{~g}$ & $53.9 \mathrm{e}-\mathrm{g}$ & $64.5 \mathrm{~cd}$ \\
\hline BRS 7 & & $68.6 \mathrm{bc}$ & $84.9 \mathrm{a}$ & $53.3 \mathrm{e}-\mathrm{g}$ & $50.6 \mathrm{~g}$ & $52.6 \mathrm{fg}$ \\
\hline IR 8 & & & $74.8 \mathrm{~b}$ & $67.6 \mathrm{~b}-\mathrm{d}$ & $62.1 \mathrm{c}-\mathrm{e}$ & $63.8 \mathrm{~cd}$ \\
\hline Quilla 64117 & & & & $64.4 \mathrm{~cd}$ & $62.4 \mathrm{c}-\mathrm{e}$ & $64.1 \mathrm{~cd}$ \\
\hline Quilla 66304 & & & & & $54.2 \mathrm{e}-\mathrm{g}$ & $66.8 \mathrm{~b}-\mathrm{d}$ \\
\hline \multirow[t]{3}{*}{ Diamante } & & & & & & $58.5 \mathrm{~d}-\mathrm{g}$ \\
\hline & \multicolumn{6}{|c|}{ Coleoptile growth (mm) } \\
\hline & IRGA 417 & BRS 7 & IR 8 & Quilla 64117 & Quilla 66304 & Diamante \\
\hline IRGA 417 & $5.7 \mathrm{c}-\mathrm{f}$ & $4.9 \mathrm{e}-\mathrm{g}$ & $3.7 \mathrm{fg}$ & $5.2 \mathrm{~d}-\mathrm{g}$ & $5.2 \mathrm{~d}-\mathrm{g}$ & $2.9 \mathrm{~g}$ \\
\hline BRS 7 & & $5.8 \mathrm{c}-\mathrm{f}$ & $3.1 \mathrm{~g}$ & $3.7 \mathrm{fg}$ & $3.6 \mathrm{fg}$ & $5.1 \mathrm{~d}-\mathrm{g}$ \\
\hline IR 8 & & & $8.3 \mathrm{~b}$ & $5.9 \mathrm{c}-\mathrm{f}$ & $4.2 \mathrm{e}-\mathrm{g}$ & $5.0 \mathrm{~d}-\mathrm{g}$ \\
\hline Quilla 64117 & & & & $10.8 \mathrm{a}$ & $6.3 \mathrm{~b}-\mathrm{e}$ & $7.7 \mathrm{bc}$ \\
\hline Quilla 66304 & & & & & $11.5 \mathrm{a}$ & $4.0 \mathrm{e}-\mathrm{g}$ \\
\hline Diamante & & & & & & $7.3 \mathrm{~b}-\mathrm{d}$ \\
\hline
\end{tabular}

${ }^{1}$ Means followed by the same letter do not differ by Duncan's test at $\alpha=0.05$. 
Table 2 - Analysis of variance for coleoptile length reduction (\%) and coleoptile growth (mm) according to the method of Griffing (1956) in a diallel involving six rice genotypes and their $\mathrm{F}_{1}$ hybrids.

\begin{tabular}{|c|c|c|c|c|c|}
\hline \multicolumn{3}{|c|}{ Reduction in coleoptile length (\%) } & \multicolumn{3}{|c|}{ Coleoptile growth $(\mathrm{mm})$} \\
\hline Source of variation & DF & MS & Source of variation & DF & MS \\
\hline Treatment & 20 & $70.64 *$ & Treatment & 20 & $5.38^{*}$ \\
\hline GCA & 5 & $122.52 *$ & GCA & 5 & $6.49 *$ \\
\hline SCA & 15 & $53.35^{*}$ & SCA & 15 & $5.01 *$ \\
\hline Error & 40 & 8.07 & Error & 40 & 0.51 \\
\hline$\phi_{\mathrm{g}}{ }^{1}$ & 14.31 & & $\phi_{\mathrm{g}}{ }^{1}$ & 0.75 & \\
\hline$\phi_{\mathrm{s}}^{2}$ & 45.28 & & $\phi_{\mathrm{s}}^{2}$ & 4.50 & \\
\hline
\end{tabular}

Key: $\mathrm{DF}=$ degrees of freedom; MS = mean square; GCA = general combining ability; SCA = specific combining ability. $*$ Significant $(\alpha=0.01)$. ${ }^{1}$ Quadratic component associated to the GCA. ${ }^{2}$ Quadratic component associated to the SCA.

Table 3 - General combining ability (GCA) and specific combining ability (SCA) effects of six rice genotypes and their hybrids for reduction in coleoptile length $(\%)$ and coleoptile growth $(\mathrm{mm})$.

\begin{tabular}{|c|c|c|c|c|c|c|c|}
\hline & \multicolumn{6}{|c|}{ SCA values for reduction in coleoptile length } & \multirow[b]{2}{*}{ GCA } \\
\hline & IRGA 417 & BRS 7 & IR 8 & Quilla 64117 & Quilla 66304 & Diamante & \\
\hline IRGA 417 & 4.31 & -0.39 & 0.00 & $-9.28 * *$ & -3.24 & 4.29 & -1.20 \\
\hline BRS 7 & & 5.51 & $14.70^{* *}$ & $-8.18^{* *}$ & $-8.04 * *$ & $-9.11 * *$ & 0.30 \\
\hline IR 8 & & & -2.51 & -0.99 & -3.65 & -5.03 & $7.42 * *$ \\
\hline Quilla 64117 & & & & 4.54 & 5.37 & 4.00 & -1.31 \\
\hline Quilla 66304 & & & & & 0.01 & $9.53 * *$ & $-4.15^{* *}$ \\
\hline \multirow[t]{3}{*}{ Diamante } & & & & & & -1.84 & -1.07 \\
\hline & \multicolumn{6}{|c|}{ SCA values for coleoptile growth } & \\
\hline & IRGA 417 & BRS 7 & IR 8 & Quilla 64117 & Quilla 66304 & Diamante & GCA \\
\hline IRGA 417 & 1.66 & 1.02 & -0.99 & -0.98 & -0.47 & $-1.89 *$ & $-0.83 *$ \\
\hline BRS 7 & & 2.08 & $-1.43^{*}$ & $-2.32 * *$ & $-1.91 * *$ & 0.47 & $-1.00 * *$ \\
\hline IR 8 & & & 2.96 & -0.93 & $-2.12 * *$ & -0.44 & -0.18 \\
\hline Quilla 64117 & & & & 2.48 & $-1.51 * *$ & 0.77 & $1.30 * *$ \\
\hline Quilla 66304 & & & & & 4.21 & $-2.42 * *$ & $0.79^{*}$ \\
\hline Diamante & & & & & & 1.76 & -0.08 \\
\hline
\end{tabular}

*Significant $(\alpha=0.05)$. **Significant $(\alpha=0.01)$.

for only two genotypes, Quilla 66304 and IR 8, which presented negative and positive effects, respectively, indicating that Quilla 66304 is superior and IR 8 is inferior to the other genotypes included in the diallel in regards to the mean behavior of the crosses in respect of percentage of reduction in coleoptile length.

\section{Diallel analysis for coleoptile growth}

High coleoptile growth values mean that germination rapidly recovered after the cold period, indicating higher cold tolerance. The parents differed significantly for this trait, indicating the existence of variability (Table 1). Three distinct groups were formed, one presenting higher coleoptile growth and including the genotypes Quilla 66304 and Quilla 64117, another showing intermediate growth and including the Diamante and IR 8 genotypes and a further group showing lower growth was formed by the BRS 7 and IRGA 417 genotypes. The hybrids presented coleoptile growth varying from $2.9 \mathrm{~mm}$ to $7.7 \mathrm{~mm}$ and in nearly all the hybrids the $F_{1}$ mean for coleoptile growth was inferior to both of the parents, the exception being the cross between the cold tolerant genotypes Quilla 64117 and Diamante in which the $\mathrm{F}_{1}$ was intermediate.

Diallel analysis for coleoptile growth also revealed significant GCA and SCA mean squares, indicating that both additive and non-additive effects are involved (Table 2). Similarly to what was found for percentage of reduction in coleoptile length, the higher magnitude of the quadratic component associated with SCA showed that non-additive gene action was predominant.

Almost all the crosses presented negative SCA values, indicating lower coleoptile growth (Table 3), and in six crosses this effect was significant, confirming heterosis towards cold sensitivity. Only the crosses BRS 7 x IRGA 417, BRS 7 x Diamante and Quilla 64117 x Diamante presented positive SCA values, although none of these was 
significant. Four parents presented significant GCA effects, and based on this, the genotypes Quilla 64117 and Quilla 66304 may be recommended as the best parents for increased coleoptile growth and the sensitive IRGA 417 and BRS 7 genotypes as the parents that contribute most to lowering coleoptile growth (Table 3 ).

\section{Generation mean analysis for coleoptile growth}

There was not a clear distinction between the $P_{1}$ and $\mathrm{P}_{2}$ generations in most of the crosses, and the highest differences were observed in the crosses involving Quilla 64117 as the cold tolerant parent (Table 4).

The $F_{2}$ generation of all the crosses showed transgressive segregation and continuous variation, with a tendency towards the highest coleoptile growth. The highest variation was found in the cross IRGA 417 x Quilla 66304, in which the parents were less contrasting. The $\mathrm{F}_{1}$ generation presented the lowest variation for coleoptile growth and the values were similar to the parent with lower coleoptile growth (cold-sensitive) for all the crosses, indicating dominance towards cold sensitivity. The $\mathrm{BC}_{1} \mathrm{~F}_{1}$ and $\mathrm{BC}_{2} \mathrm{~F}_{1}$ generations presented a continuous distribution with the highest variation observed in the $\mathrm{BC}_{1} \mathrm{~F}_{1}$ for all the crosses studied, except the BRS 7 x Diamante cross.

The genetic effects estimated by the six parameter model were subjected to the t-test, which showed the six estimated parameters were significant in four populations. Because of this, the model could not be tested due to lack of available degrees of freedom. In two populations, however, the additive $\mathrm{x}$ dominance parameter was not significant and was not considered, which allowed us to test model adjustment with the other five parameters and one degree of freedom. The five parameter model was accepted with 0.28 and 0.21 of probability for the crosses IRGA $417 \mathrm{x}$ Quilla 64117 and IRGA 417 x Diamante, respectively (Table 4). In all the crosses studied dominance was the most important estimated genetic effect, as indicated by its high absolute value, followed by additive $\mathrm{x}$ additive and dominance $\mathrm{x}$ dominance effects, while additive effects were low in all the crosses.

\section{Heritabilities}

Genetic variance estimates were superior to the environmental variance for all the crosses (Table 5) and, consequently, nearly all of the crosses presented high values for broad sense heritability, the exception being the two crosses involving Diamante as the cold tolerant parent, which presented moderate heritability. Among the cold tolerant parents, Diamante presented the lowest coleoptile growth (Table 1), so it was the least different from the sensitive genotypes, thus lowering the genetic variance in the crosses in which it was involved.

\section{Discussion}

Rice cold tolerance at the germination stage was evaluated using both percentage of reduction in coleoptile

Table 4 - Coleoptile growth (mm) means for the $\mathrm{P}_{1}, \mathrm{P}_{2}, \mathrm{~F}_{1}, \mathrm{~F}_{2}, \mathrm{BC}_{1} \mathrm{~F}_{1}$ and $\mathrm{BC}_{2} \mathrm{~F}_{1}$ generations, number of evaluated seeds in each generation (in parenthesis), genetic effect values and of the chi square $\left(\chi^{2}\right)$ for coleoptile growth obtained for six rice crosses.

\begin{tabular}{|c|c|c|c|c|c|c|}
\hline $\begin{array}{l}\text { Generation, genetic } \\
\text { effect and } \chi^{2} \text { values }\end{array}$ & $\begin{array}{c}\text { BRS } 7\left(\mathrm{P}_{2}\right) \mathrm{x} \\
\text { Quilla } 66304\left(\mathrm{P}_{1}\right)\end{array}$ & $\begin{array}{c}\text { BRS } 7\left(\mathrm{P}_{2}\right) \mathrm{x} \\
\text { Quilla } 64117\left(\mathrm{P}_{1}\right)\end{array}$ & $\begin{array}{l}\text { BRS } 7\left(\mathrm{P}_{2}\right) \mathrm{x} \\
\text { Diamante }\left(\mathrm{P}_{1}\right)\end{array}$ & $\begin{array}{l}\text { IRGA } 417\left(\mathrm{P}_{2}\right) \mathrm{x} \\
\text { Quilla } 66304\left(\mathrm{P}_{1}\right)\end{array}$ & $\begin{array}{l}\text { IRGA } 417\left(\mathrm{P}_{2}\right) \mathrm{x} \\
\text { Quilla } 64117\left(\mathrm{P}_{1}\right)\end{array}$ & $\begin{array}{c}\text { IRGA } 417\left(\mathrm{P}_{2}\right) \mathrm{x} \\
\text { Diamante }\left(\mathrm{P}_{1}\right)\end{array}$ \\
\hline \multicolumn{7}{|l|}{ Generation } \\
\hline $\mathrm{P}_{1}$ & $10.6 \pm 3.8(27)$ & $13.8 \pm 4.4(21)$ & $15.2 \pm 4.2(43)$ & $11.5 \pm 5.0(47)$ & $16.1 \pm 4.3(25)$ & $11.0 \pm 4.2(48)$ \\
\hline $\mathrm{P}_{2}$ & $5.2 \pm 2.7(48)$ & $5.0 \pm 2.5(19)$ & $8.7 \pm 3.3(56)$ & $8.7 \pm 4.4(20)$ & $8.6 \pm 5.1(28)$ & $5.7 \pm 2.6(54)$ \\
\hline $\mathrm{F}_{1}$ & $4.2 \pm 2.2(13)$ & $5.9 \pm 0.8(6)$ & $8.3 \pm 2.6(21)$ & $2.9 \pm 1.6(4)$ & $8.0 \pm 4.2(11)$ & $2.5 \pm 1.4(2)$ \\
\hline $\mathrm{F}_{2}$ & $16.7 \pm 6(218)$ & $17.5 \pm 6.0(203)$ & $15.7 \pm 5.1(234)$ & $18.0 \pm 7.8(159)$ & $16.8 \pm 7.0(190)$ & $11.6 \pm 6.5(155)$ \\
\hline $\mathrm{BC}_{1} \mathrm{~F}_{1}$ & $9.1 \pm 4.7(122)$ & $3.8 \pm 3.4(64)$ & $6.3 \pm 4.9(79)$ & $6.6 \pm 5.1(96)$ & $8.1 \pm 4.4(108)$ & $7.6 \pm 3.8(134)$ \\
\hline $\mathrm{BC}_{2} \mathrm{~F}_{1}$ & $2.9 \pm 2.8(33)$ & $1.2 \pm 1.8(66)$ & $6.5 \pm 5.5(41)$ & $0.9 \pm 1.8(20)$ & $3.3 \pm 3.5(79)$ & $4.2 \pm 2.5(48)$ \\
\hline \multicolumn{7}{|l|}{ Genetic effects } \\
\hline Mean (m) & $50.5 \pm 2.1^{*}$ & $69.6 \pm 2.0^{*}$ & $49.3 \pm 2.5^{*}$ & $67.2 \pm 2.9^{*}$ & $57.0 \pm 2.4^{*}$ & $31.0 \pm 2.3^{*}$ \\
\hline Additive $[\mathrm{d}]$ & $2.7 \pm 0.4^{*}$ & $4.4 \pm 0.5 *$ & $3.3 \pm 0.3 *$ & $1.4 \pm 0.6^{*}$ & $4.3 \pm 0.4^{*}$ & $2.9 \pm 0.3^{*}$ \\
\hline Dominance $[\mathrm{h}]$ & $-89.2 \pm 5.2^{*}$ & $-144.6 \pm 4.8^{*}$ & $-93.3 \pm 6.8^{*}$ & $-132.7 \pm 6.7^{*}$ & $111.6 \pm 5.8^{*}$ & $-49.2 \pm 5.3^{*}$ \\
\hline Additive $\mathrm{x}$ additive [i] & $-42.7 \pm 2.1^{*}$ & $-60.2 \pm 1.9^{*}$ & $-37.3 \pm 2.4^{*}$ & $-57.1 \pm 2.8^{*}$ & $-44.7 \pm 2.3^{*}$ & $-22.6 \pm 2.3^{*}$ \\
\hline Additive $\mathrm{x}$ dominance $[\mathrm{j}]$ & $7.1 \pm 1.5^{*}$ & $-3.7 \pm 1.5^{*}$ & $-7.0 \pm 2.2^{*}$ & $8.5 \pm 1.8^{*}$ & $-*$ & - \\
\hline $\begin{array}{l}\text { Dominance } \mathrm{x} \\
\text { dominance[1] }\end{array}$ & $42.9 \pm 3.4^{*}$ & $80.9 \pm 2.9^{*}$ & $52.2 \pm 4.5^{*}$ & $68.3 \pm 4.2 *$ & $62.6 \pm 4.2 *$ & $20.7 \pm 3.6^{*}$ \\
\hline \multicolumn{7}{|l|}{ Chi-square test } \\
\hline$\chi^{2}$ & - & - & - & - & 1.21 & 1.58 \\
\hline Degrees of freedom & - & - & - & - & 1.00 & 1.00 \\
\hline Probability values & - & - & - & - & 0.28 & 0.21 \\
\hline
\end{tabular}

*Significant genetic effects $(\alpha=0.05)$. ${ }^{*}$ Genetic effect not considered because it was not significant $(\alpha=0.05) .{ }^{1}$ Not calculated due to insufficient degrees of freedom. 
length and coleoptile growth. These traits were chosen as they proved to be the most adequate ones to differentiate cold tolerant from cold sensitive genotypes at the germination stage (Cruz and Milach, 2004). Although the measurements for the two traits were made using different procedures similar genetic effects were observed for both of them in the diallel analysis, indicating the greater importance of non-additive effects in comparison to additive effects in the crosses studied. According to Cruz and Regazzi (1994), such results are observed in diallels in which the parents have been submitted to previous selection for the trait under study, which reduces the differential for the additive effects and increases the importance of the nonadditive effects. In fact, the cold tolerant genotypes studied were originally from Chile where the genotypes have been systematically selected for low temperature germination. In similar studies regarding rice cold tolerance at the vegetative and reproductive stages non-additive effects have also been reported to be more important than additive ones (Datta and Siddiq, 1983; Kaw and Khush, 1987). However, Nishimura and Hamamura (1993) have reported the predominance of additive gene action over dominance action for cold tolerance at the booting stage in Japanese rice genotypes.

Generation means analysis for coleoptile growth also showed that the non-additive effects predominated over additive effects. Table 4 shows that non-additive gene action was not only due to dominance, but also to additive $\mathrm{x}$ additive and dominance $\mathrm{x}$ dominance effects, suggesting that the genes controlling cold tolerance at the germination stage do not act independently. When there are many pairs of interacting genes, the classification of gene interactions that depend on the relative magnitude and sign of the estimates of the six parameters must largely depend on the magnitudes and signs of the estimates of dominance and dominance $\mathrm{x}$ dominance effects (Mather and Jinks, 1982). Based on this, duplicate genes is the predominant type of gene interaction in the six crosses studied with negative dominance (negative sign for [h] and positive sign for [1]).

The sign associated with the estimates of $[\mathrm{d}]$ and $[\mathrm{h}]$ indicates the parent that concentrates the highest number of genes for increasing the trait, and by convention the positive sign is used for $\mathrm{P}_{1}$ and the negative sign for $\mathrm{P}_{2}$ (Falconer, 1989). So, the positive sign for [d] in all the crosses indicates that the Japonica genotypes $\left(\mathrm{P}_{1}\right)$ presented the highest number of genes for increasing coleoptile growth. The negative sign for $[\mathrm{h}]$ demonstrated that the dominance was towards the sensitive parent $\left(\mathrm{P}_{2}\right)$, the Indica genotypes. The negative and positive signs for [i] and [1], respectively, indicated that the additive $\mathrm{x}$ additive interactions were towards $\mathrm{P}_{2}$ and the dominance $\mathrm{x}$ dominance ones towards $\mathrm{P}_{1}$. Based on this, it is worth emphasizing that the magnitude of the additive $\mathrm{x}$ additive and dominance $\mathrm{x}$ dominance effects was almost identical in the crosses BRS 7 x Quilla 66304 and IRGA $417 \times$ Diamante, indicating that the genes for increasing coleoptile growth are dispersed between the parents. In fact, there was a certain degree of phenotypic similarity between the parents regarding coleoptile growth, which is in agreement with the low additive genetic effects of the crosses. This does not mean lack of variability for coleoptile growth between the parents, but, as mentioned above, that the genes that contribute to increasing it are present in both parents so that the additive effects are neutralized. Further evidence for this is presented by the continuous distribution and transgressive segregation of the $F_{2}$ generation for coleoptile growth, which indicates that the genes involved in cold tolerance are complementarily distributed between the parents in the six crosses studied. The tendency of the $\mathrm{F}_{2}$ generation towards the higher coleoptile growth may be a consequence of the dominance $\mathrm{x}$ dominance effects. Transgressive segregation towards the cold tolerant parent was also observed in a study conducted for quantitative trait loci (QTL) mapping of rice germination under cold conditions (Suh et al., 1999). The low individual contribution of the detected QTL for phenotypic variation and the absence of interaction between the QTL suggest quantitative inheritance for cold tolerance at the germination stage. Similarly, Miura et al. (2004) detected five putative QTL related to low temperature $\left(15^{\circ} \mathrm{C}\right.$ for four days $)$ germination in four rice chromosomes, confirming the quantitative nature of this trait in rice.

Diallel analysis is an important tool for choosing the best parents and combination of parents in a breeding program. For coleoptile growth, no hybrids showed specific combining abilities (SCA) in the desired direction and the general combining abilities (GCA) were relatively similar among the parents. In contrast, for percentage of reduction in coleoptile length some hybrids showed significant SCA

Table 5 - Broad sense heritabilities $\left(\mathrm{h}_{\mathrm{b}}{ }_{\mathrm{b}}\right)$ and phenotypic, environmental and genetic variances for coleoptile growth in six rice crosses.

\begin{tabular}{lcccc}
\hline Cross & \multicolumn{3}{c}{ Variances } & $\mathrm{h}^{2} \mathrm{~b}$ \\
\cline { 2 - 4 } & Phenotypic & Environmental & Genetic & \\
\hline BRS 7 x Quilla 66304 & 36.5 & 7.8 & 28.7 & 0.79 \\
BRS 7 x Quilla 64117 & 36.1 & 6.9 & 29.2 & 0.81 \\
BRS 7 x Diamante & 26.1 & 10.4 & 15.7 & 0.60 \\
IRGA 417 x Quilla 66304 & 42.9 & 7.0 & 35.9 & 0.84 \\
IRGA 417 x Quilla 64117 & 61.6 & 12.3 & 49.3 & 0.80 \\
IRGA 417 x Diamante & 48.9 & 20.2 & 28.7 & 0.59 \\
\hline
\end{tabular}


for cold tolerance and larger GCA differences were observed among the parents. The reduction in coleoptile length may be a better indicator of cold tolerance at the germination stage because, according to Datta and Siddiq (1983), it is obtained from the comparison between two distinct conditions (cold versus control) and has the advantage of allowing the study of the genetic components of tolerance per se rather than those related to the trait under stress. Four hybrid combinations showed significant SCA effects for this trait in the desired direction, indicating the importance of non-additive gene action in these crosses. All of these hybrid combinations are recommended for recovering superior segregants in advanced generations, especially the cross BRS 7 x Quilla 66304 which involved a parent with good GCA and so must be a promising cross for obtaining desirable transgressive segregants. SCA and GCA estimates depended on the trait but in spite of this Quilla 66304 presented high GCA for both traits and can therefore be recommended as a parent in crosses aimed at raising the cold tolerance of germinating rice.

The high broad sense heritability obtained for coleoptile growth indicates good genetic gains when selecting for cold tolerance at the germination stage through this trait. In our study, however, a significant portion of the genetic variance was due to non-additive effects, based on which we recommend selecting for coleoptile growth in more advanced generations which have higher degree of homozygosis and when the major portion of the observed genetic variation is due to additive variance. This is also true in the case of percentage of reduction in coleoptile length, not only because of the non-additive effects but also because this trait is not suitable for measurement in early generations since it requires exposure of the same genotype to two different temperatures. According to Acharya (1987), rice cold tolerance should be based on the exploitation of both additive and non-additive gene action, which may be achieved through the reciprocal recurrent selection breeding method and which is likely to hasten the rate of genetic improvement. Recent evidence (Qian et al., 2000) that cold tolerance genes are related to the differentiation of Indica and Japonica subspecies also shows the importance of this type of method for cold tolerance breeding in Brazil as a means of retaining the adaptability of Indica while improving cold tolerance.

\section{References}

Acharya S (1987) Genetic parameters and their implication in breeding cold tolerant varieties of rice (Oryza sativa L.). Crop Improv 14:100-103.
Blum A (1988) Cold resistance. In: Blum A (ed) Plant Breeding for Stress Environments. CRC, Boca Raton, pp 99-132.

Cruz CD and Regazzi AJ (1994) Modelos biométricos aplicados ao melhoramento genético. UFV, Viçosa, $390 \mathrm{pp}$.

Cruz RP da and Milach SCK (2004) Cold tolerance at the germination stage of rice: Methods of evaluation and characterization of genotypes. Sci Agric 61:1-8.

Datta D and Siddiq EA (1983) Genetic analysis of cold tolerance at seedling phase in rice. Indian J Genet P Breed 43:345-349.

Falconer DS (1989) Introduction to Quantitative Genetics. 3rd edition. Longman Scientific and Technical, Harlow, 463 pp.

Griffing B (1956) Concept of general and specific combining ability in relation to diallel crossing systems. Austr J Biol Sci 9:463-493.

Kaw RN, Visperas RM, Moon HP and Yae JD (1986) Estimates of combining ability for vegetative stage cold tolerance in rice. Korean J Breed 18:48-52.

Kaw RN and Khush GS (1986) Combining ability for low-temperature tolerance in rice. Proceedings International Rice Genetics Symposium, Los Baños, Philippines, pp 593-612.

Kaw RN and Khush GS (1987) Estimates of combining ability for cold stability in rice. Oryza 24:19-23.

Li CC and Rutger JN (1980) Inheritance of cool-temperature seedling vigor in rice and its relationship with other agronomic characters. Crop Sci 20:295-298.

Mather SK and Jinks JL (1982) Biometrical Genetics. $3^{\text {rd }}$ edition. Chapman and Hill, London, 396 pp.

Miura K, Lin SY, Araki H, Nagamine T, Kuroki M, Shimizu H, Ando I and Yano M (2004) Genetical studies on germination of seed and seedling establishment for breeding of improved rice varieties suitable for direct seeding culture. Jarq 38:1-5.

Nishimura, M and Hamamura, K (1993) Diallel analysis of cool tolerance at the booting stage in rice varieties from Hokkaido. Jpn J Breed 43:557-566.

Qian Q, Zeng D, He P, Zheng X, Chen Y and Zhu L (2000) QTL analysis of the rice seedling cold tolerance in a double haploid population derived from anther culture of a hybrid between indica and japonica rice. Chinese Sci Bull 45:448-453.

Sthapit BR and Witcombe JR (1998) Inheritance of tolerance to chilling stress in rice during germination and plumule greening. Crop Sci 38:660-665.

Suh JP, Ahn SN, Moon HP and Suh HS (1999) QTL analysis of low temperature germinability in a Korean weedy rice (Oryza sativa L.). Rice Genet Newsl 16:53-55.

Takahashi N (1984) Differentiation of ecotypes in Oryza sativa L. In: Takahashi $\mathrm{N}$ and Tsunoda S (eds) Biology of Rice. Japan Scientific Societies Press, Tokyo, pp 31-67.

Takahashi N (1997) Inheritance of seed germination and dormancy. In: Matsuo T, Futsuhara Y, Kikuchi F and Yamaguchi H (eds) Science of the Rice Plant: Genetics. Food and Agriculture. Policy Research Center, Tokyo, pp 348-359.

Yoshida, S (1981) Climatic environment and its influence. In: Yoshida S (ed) Fundamentals of Rice Crop Science. International Rice Research Institute, Los Baños, pp 65-110.

Associate Editor: Everaldo Gonçalves de Barros 